\title{
EFFECTS OF THYROXINE AS COMPARED WITH THYROXINE PLUS TRIIODOTHYRONINE IN PATIENTS WITH HYPOTHYROIDISM
}

\author{
Robertas Bunevičıus, M.D., Ph.D., Gintautas Kažanavičıus, M.D., Ph.D., Rimas Žalinkevičıus, M.D., \\ and Arthur J. Prange, JR., M.D.
}

\begin{abstract}
Background Patients with hypothyroidism are usually treated with thyroxine (levothyroxine) only, although both thyroxine and triiodothyronine are secreted by the normal thyroid gland. Whether thyroid secretion of triiodothyronine is physiologically important is unknown.

Methods We compared the effects of thyroxine alone with those of thyroxine plus triiodothyronine (liothyronine) in 33 patients with hypothyroidism. Each patient was studied for two five-week periods. During one period, the patient received his or her usual dose of thyroxine. During the other, the patient received a regimen in which $50 \mu \mathrm{g}$ of the usual dose of thyroxine was replaced by $12.5 \mu \mathrm{g}$ of triiodothyronine. The order in which each patient received the two treatments was randomized. Biochemical, physiologic, and psychological tests were performed at the end of each treatment period.
\end{abstract}

Results The patients had lower serum free and total thyroxine concentrations and higher serum total triiodothyronine concentrations after treatment with thyroxine plus triiodothyronine than after thyroxine alone, whereas the serum thyrotropin concentrations were similar after both treatments. Among 17 scores on tests of cognitive performance and assessments of mood, 6 were better or closer to normal after treatment with thyroxine plus triiodothyronine. Similarly, among 15 visual-analogue scales used to indicate mood and physical status, the results for 10 were significantly better after treatment with thyroxine plus triiodothyronine. The pulse rate and serum sex hormone-binding globulin concentrations were slightly higher after treatment with thyroxine plus triiodothyronine, but blood pressure, serum lipid concentrations, and the results of neurophysiologic tests were similar after the two treatments.

Conclusions In patients with hypothyroidism, partial substitution of triiodothyronine for thyroxine may improve mood and neuropsychological function; this finding suggests a specific effect of the triiodothyronine normally secreted by the thyroid gland. (N Engl J Med 1999;340:424-9.)

(c)1999, Massachusetts Medical Society.

HERE are two thyroid hormones, thyroxine and triiodothyronine. The daily production of thyroxine is about $100 \mu \mathrm{g}$, all produced by the thyroid gland. The daily production of triiodothyronine is about $30 \mu \mathrm{g}$, of which about 20 percent is produced by the thyroid gland and 80 percent by deiodination of thyroxine in extrathyroidal tissues. ${ }^{1}$ Not all tissues that need thyroid hormone are equally able to convert thyroxine to triiodothyronine, the active form of the hormone. ${ }^{2} \mathrm{Nev}$ ertheless, most patients with hypothyroidism are treated only with thyroxine (levothyroxine). Although this treatment is effective, some patients with hypothyroidism treated with thyroxine are not entirely well. ${ }^{3}$ This observation, plus the existence of differences in the rate of conversion of thyroxine to triiodothyronine in different tissues, ${ }^{2}$ prompted us to compare the effects of thyroxine alone with those of thyroxine plus triiodothyronine (liothyronine) on thyroid hormone actions in the brain, pituitary gland, and other organs in patients with hypothyroidism.

\section{METHODS}

\section{Patients}

We invited patients with chronic autoimmune thyroiditis or thyroid cancer treated by near-total thyroidectomy who received care at the Institute of Endocrinology of Kaunas Medical University in Kaunas, Lithuania, to participate in the study if they were totally, or nearly totally, dependent on exogenous thyroxine. The patients with chronic autoimmune thyroiditis were receiving replacement therapy with thyroxine, and the patients with cancer were receiving thyroxine as suppressive therapy. Patients with other serious medical illnesses were excluded.

Thirty-five patients were enrolled, and 33 completed the study: 31 women and 2 men, with a mean $( \pm S D)$ age of $46 \pm 13$ years (Table 1). Sixteen patients had chronic autoimmune thyroiditis, and 17 had thyroid cancer. The mean dose of thyroxine at base line was $175 \pm 53 \mu \mathrm{g}$ per day; the range was from $100 \mu \mathrm{g}$ per day (five patients) to $300 \mu \mathrm{g}$ per day (two patients). The mean duration of treatment was $73 \pm 72$ months. In all patients the dosage had been stable for at least three months. The mean score on the Hamilton Rating Scale for Depression (the 21-item "long" version) was $9.8 \pm 5.4$, on a scale from 0 (indicating no depression) to 69 (the maximal theoretical score). ${ }^{4}$ Four women had major depression, as defined and diagnosed by standard instruments. ${ }^{5,6}$ One patient withdrew from the study because she became pregnant, and another because of anxiety. The study was approved by the institutional review board of Kaunas Medical University, and all patients gave written informed consent.

\section{Study Protocol}

Patients took their usual dose of thyroxine through the first day of the study. On this day each patient was assigned, according to a prearranged randomization schedule, either to receive thyroxine alone for five weeks, then thyroxine plus triiodothyronine for five weeks, or to receive thyroxine plus triiodothyronine for five weeks, then thyroxine alone for five weeks. The thyroxine (BerlinChemie, Berlin, Germany) was given as $50-\mu$ g tablets at each pa-

From the Institute of Endocrinology, Kaunas Medical University, Kaunas, Lithuania (R.B., G.K., R.Z.); and the Department of Psychiatry, School of Medicine, University of North Carolina, Chapel Hill (A.J.P.). Address reprint requests to Dr. Prange at the Department of Psychiatry, School of Medicine, University of North Carolina at Chapel Hill, Campus Box 7160, Room 254, Wing D - Medical School, Chapel Hill, NC 27599-7160. 
Table 1. Base-Line Characteristics of the Study Patients.*

\begin{tabular}{|c|c|c|c|}
\hline Characteristic & $\begin{array}{l}\text { THYROXINE } \\
\text { FIRST } \\
(\mathbf{N}=17)\end{array}$ & $\begin{array}{c}\text { THYROXINE PLUS } \\
\text { TRIIODOTHYRONINE } \\
\text { FIRST } \\
\text { (N=16) }\end{array}$ & $\begin{array}{c}\text { ALL } \\
\text { PATIENTS } \\
(\mathbf{N}=33)\end{array}$ \\
\hline \multicolumn{4}{|l|}{ Sex (no. of patients) } \\
\hline Female & 15 & 16 & 31 \\
\hline Male & 2 & 0 & 2 \\
\hline Age $(y r)$ & $45 \pm 10$ & $48 \pm 15$ & $46 \pm 13$ \\
\hline \multicolumn{4}{|l|}{$\begin{array}{l}\text { Cause of hypothyroidism } \\
\text { (no. of patients) }\end{array}$} \\
\hline $\begin{array}{l}\text { Chronic autoimmune } \\
\text { thyroiditis }\end{array}$ & 4 & 12 & 16 \\
\hline Thyroid cancer & 13 & 4 & 17 \\
\hline $\begin{array}{l}\text { Prestudy dose of thyroxine } \\
\qquad(\mu \mathrm{g} / \text { day })\end{array}$ & $181 \pm 56$ & $169 \pm 51$ & $175 \pm 53$ \\
\hline Duration of therapy (mo) & $54 \pm 41$ & $92 \pm 96$ & $73 \pm 72$ \\
\hline Serum thyrotropin $(\mu \mathrm{U} / \mathrm{ml})$ & $0.3 \pm 0.8$ & $1.5 \pm 1.8$ & $0.7 \pm 1.4$ \\
\hline $\begin{array}{l}\text { No. of patients with undetect- } \\
\text { able serum thyrotropin } \\
(<0.05 \mu \mathrm{U} / \mathrm{ml})\end{array}$ & 1 & 2 & 3 \\
\hline Serum free thyroxine $(\mathrm{ng} / \mathrm{dl}) \dagger$ & $2.0 \pm 0.7$ & $1.9 \pm 0.5$ & $2.0 \pm 0.6$ \\
\hline Hamilton depression score & $10.0 \pm 5.5$ & $9.5 \pm 5.3$ & $9.8 \pm 5.4$ \\
\hline $\begin{array}{l}\text { Current depression (no. of } \\
\text { patients) } \mathbb{S}\end{array}$ & 2 & 2 & 4 \\
\hline
\end{tabular}

*Plus-minus values are means \pm SD.

$\dagger$ To convert values for serum free thyroxine to picomoles per liter, multiply by 12.87

$\ddagger$ The 21 -item version of the Hamilton Rating Scale for Depression was used. ${ }^{4}$

SCurrent depression was determined with use of the Structured Clinical Interview in the Diagnostic and Statistical Manual of Mental Disorders, third edition, revised. 5,6

tient's usual total dose, but $50 \mu \mathrm{g}$ of the dose of thyroxine was replaced by a capsule. These capsules contained either $50 \mu \mathrm{g}$ of thyroxine or $12.5 \mu \mathrm{g}$ of triiodothyronine (Berlin-Chemie), depending on the assigned treatment. They were prepared by a pharmacist and were identical in appearance. If, for example, a patient had been treated with $200 \mu \mathrm{g}$ of thyroxine per day, he or she was instructed to take $150 \mu \mathrm{g}$ of the usual thyroxine tablets plus one capsule each morning. If the patient had been assigned to receive thyroxine alone, the capsule contained $50 \mu \mathrm{g}$ of thyroxine; if the patient had been assigned to receive thyroxine plus triiodothyronine, the capsule contained $12.5 \mu \mathrm{g}$ of triiodothyronine. Patients took the medications once daily, half an hour before breakfast.

At the end of each five-week period, the patients were given another batch of tablets and capsules. Only the pharmacist knew which capsules had been dispensed. At the end of each treatment phase, all patients, when asked, said that they had taken their medications as instructed, but remaining pills were not counted.

\section{Evaluations}

The patients were systematically studied on the last day of each five-week treatment period. They reported to the clinic at about 9 a.m., having omitted breakfast but having taken their thyroid hormone about two hours earlier. Venous blood was taken for measurements of serum thyrotropin, thyroid hormones, cholesterol, triglycerides, and sex hormone-binding globulin. ${ }^{7}$ Physiologic tests were performed. Assessments were made of cognitive function and psychological state. Each patient had the same examiner for whatever variable was being measured at each session, and the examiners were unaware of the patients' treatment assignments.

\section{Biochemical Measurements}

Serum samples were frozen, allowing the samples from all the patients to be analyzed at the same time for each variable. Serum thyrotropin was measured by immunoradiometric assay with kits obtained from Orion Diagnostica (Espoo, Finland), with a sensitivity of $0.05 \mu \mathrm{U}$ per milliliter. Serum free and total thyroxine and triiodothyronine were measured with radioimmunoassay kits (Orion Diagnostica). Serum total cholesterol and triglycerides were measured by enzymatic colorimetric methods (Sera-Pak Cholesterol Fast Color kit and Sera-Pak Triglycerides Fast Color kit, Bayer, Tarrytown, N.Y.). Serum sex hormone-binding globulin was measured with immunoenzymometric assay kits (Medix Biochemica, Kauniainen, Finland). The intraassay variation ranged from 3 to 6 percent.

\section{Physiologic Measurements \\ Cardiovascular System}

The pulse rate was recorded after the patient had been supine for five minutes. Blood pressure was measured in the sitting position. Electrocardiography was performed at both sessions, and all the results were normal.

\section{Peripheral Nervous System}

The sensory threshold (minimal detectable intensity of vibration) was measured with a biothesiometer (Model PVD, Biomedical, Newbury, Ohio) applied to the tip of the fourth finger and the tip of the fourth toe. ${ }^{8}$ The Achilles tendon reflex was measured with an electroneuromyograph (Type LT1, Medicor, Budapest, Hungary) ${ }^{9}$

\section{Psychological Assessment}

Psychological assessment was performed according to the $\mathrm{Di}$ agnostic and Statistical Manual of Mental Disorders, third edition, revised (DSM-III-R). ${ }^{5}$ Symptoms were recorded according to the Structured Clinical Interview of the DSM-III-R for assessment of nonpsychotic disorders (Lithuanian edition). ${ }^{6}$

Cognitive functioning was assessed by three standard tests: the Digit Symbol Test, ${ }^{10}$ the Digit Span Test of the Wechsler Adult Intelligence Scale, ${ }^{10}$ and the Visual Scanning Test. ${ }^{11}$ In the Digit Symbol Test, a key is provided that pairs each of the numbers 1 through 9 with a nonsense symbol. Below are rows of pairs of squares, the upper of which contains a number, the lower of which is blank. With the key available, the subject is allowed 90 seconds to complete each pair of squares by entering the appropriate symbol. The raw score is the number of correct entries completed in 90 seconds or until completion of the third row, whichever occurs first. This score measures psychomotor performance. With the key unavailable, the subject is then asked to recall which symbol matched each number. The number of pairs correctly recalled is a measure of incidental learning. Then the subject copies 70 symbols. The less time is required for completion, the greater the subject's psychomotor speed.

The first part of the Digit Span Test requires the subject to repeat spoken numbers with increasing numbers of digits; it measures immediate auditory attention. The second part, which requires the subject to repeat the numbers in reverse order, measures mental flexibility.

The Visual Scanning Test assesses distractibility and visual inattentiveness. The subject is shown a "target" symbol and then presented with a paper with a matrix of symbols containing 60 targets. The patient circles all the target symbols that he or she can find. The time needed to complete the test, omissions, and errors are scored.

The Hamilton Rating Scale for Depression (21-item "long" version $)^{4}$ was used to assess the severity of depressive symptoms. Clinically important depression is associated with scores of 20 or more.

Three scales were completed by the patients: the Beck Depression Inventory, ${ }^{12}$ the Spielberger State-Trait Anxiety Inventory, ${ }^{13}$ 
Table 2. Biochemical and Physiologic Values at the End of Each Treatment Period.*

\begin{tabular}{|c|c|c|c|c|}
\hline Valuet & $\begin{array}{c}\text { AFTER } \\
\text { THYROXINE } \\
(\mathbf{N}=\mathbf{3 3})\end{array}$ & $\begin{array}{l}\text { AfTER THYROXINE } \\
\text { PLUS } \\
\text { TRIIODOTHYRONINE } \\
(\mathbf{N}=\mathbf{3 3})\end{array}$ & $\begin{array}{c}\mathbf{P} \\
\text { VALUE }\end{array}$ & $\begin{array}{l}\text { NORMAL } \\
\text { RANGE }\end{array}$ \\
\hline Serum thyrotropin $(\mu \mathrm{U} / \mathrm{ml})$ & $0.8 \pm 2.5$ & $0.5 \pm 1.1$ & 0.56 & $0.3-5.0$ \\
\hline $\begin{array}{l}\text { No. of patients with undetectable serum } \\
\text { thyrotropin }(<0.05 \mu \mathrm{U} / \mathrm{ml})\end{array}$ & 7 & 5 & - & - \\
\hline Serum free thyroxine $(\mathrm{ng} / \mathrm{dl})$ & $2.3 \pm 0.7$ & $1.8 \pm 0.6$ & $<0.001$ & $0.7-2.1$ \\
\hline Serum total thyroxine $(\mu \mathrm{g} / \mathrm{dl})$ & $15.2 \pm 3.8$ & $11.3 \pm 3.3$ & $<0.001$ & $4-11$ \\
\hline Serum total triiodothyronine $(\mathrm{ng} / \mathrm{dl})$ & $87 \pm 38$ & $117 \pm 42$ & $<0.001$ & $75-175$ \\
\hline Serum triglycerides $(\mathrm{mg} / \mathrm{dl})$ & $129 \pm 54$ & $132 \pm 55$ & 0.76 & $47-228$ \\
\hline Serum cholesterol (mg/dl) & $219 \pm 46$ & $217 \pm 43$ & 0.66 & $152-268$ \\
\hline $\begin{array}{l}\text { Serum sex hormone-binding globulin } \\
\qquad(\mu \mathrm{g} / \mathrm{dl})\end{array}$ & $2.6 \pm 1.3$ & $3.1 \pm 1.5$ & 0.007 & $0.4-3.5$ \\
\hline Pulse rate at rest (beats/min) & $69 \pm 11$ & $72 \pm 12$ & 0.04 & - \\
\hline $\begin{array}{l}\text { Blood pressure while seated }(\mathrm{mm} \mathrm{Hg}) \\
\text { Systolic } \\
\text { Diastolic }\end{array}$ & $\begin{array}{r}130 \pm 21 \\
79 \pm 12\end{array}$ & $\begin{array}{r}124 \pm 18 \\
77 \pm 14\end{array}$ & $\begin{array}{l}0.18 \\
0.52\end{array}$ & - \\
\hline $\begin{array}{l}\text { Sensory threshold }(\mathrm{V}) \\
\text { 4th Finger } \\
\text { 4th Toe }\end{array}$ & $\begin{array}{l}7.5 \pm 2.6 \\
9.4 \pm 3.0\end{array}$ & $\begin{array}{l}7.4 \pm 2.4 \\
9.3 \pm 2.9\end{array}$ & $\begin{array}{l}0.87 \\
0.89\end{array}$ & $\begin{array}{l}6-10 \\
8-12\end{array}$ \\
\hline Achilles reflex relaxation half-time (msec) & $282 \pm 22$ & $286 \pm 28$ & 0.28 & $240-320$ \\
\hline
\end{tabular}

*Plus-minus values are means \pm SD.

†To convert values for serum free and total thyroxine to picomoles per liter and nanomoles per liter, respectively, multiply by 12.87 . To convert values for serum triiodothyronine to nanomoles per liter, multiply by 0.015 . To convert values for triglycerides to millimoles per liter, multiply by 0.01129 . To convert values for cholesterol to millimoles per liter, multiply by 0.02586 .

$\ddagger P$ values were calculated by paired t-tests.

and the Profile of Mood States. ${ }^{14}$ The Beck Depression Inventory is a self-rating scale of 21 items, in which scores of 10 or less indicate normal mood variation and scores of 11 or more reflect increasing degrees of depression. The Spielberger State-Trait Anxiety Inventory is a self-rating scale consisting of 20 items; scores below 50 are normal. The Profile of Mood States assesses affective states. The subject rates 65 items, each pertaining to an aspect of subjective state, on a scale from 0 to 4 . When the scores for combinations of items are added, values for six aspects of mood and a global score are obtained.

Fifteen visual-analogue scales provided more detailed ratings of mood and physical symptoms by the patients. Each scale consisted of a pair of phrases, such as "as sad as possible" and "as happy as possible," at either end of a $100-\mathrm{mm}$ line. The patient placed a mark at the point best corresponding to his or her state at that time. Measurement of the marks from the beginning of the line generated a score.

At the completion of the study, each patient was asked which treatment (the first or the second) he or she preferred.

\section{Statistical Analysis}

Paired t-tests were used to compare paired data from the two treatment periods. Nonpaired t-tests were used to compare values in subgroups of patients - for example, depressed and nondepressed patients. Results pertaining to the patients' treatment preferences were evaluated with use of McNemar's test. Probability values were based on two-sided analyses of test results.

\section{RESULTS}

The patients' biochemical and physiologic values after each treatment period are shown in Table 2. As expected, the mean serum free and total thyroxine concentrations were lower and the mean serum total triiodothyronine concentration was higher after treatment with thyroxine plus triiodothyronine than after treatment with thyroxine alone. The mean serum thyrotropin concentrations were similar after the two treatments. The mean serum cholesterol and triglyceride concentrations also were similar after the two treatments, whereas the mean serum sex hormonebinding globulin concentration was significantly higher after treatment with thyroxine plus triiodothyronine, suggesting that thyroid hormone action was greater after treatment with thyroxine plus triiodothyronine. The mean pulse rate at rest was slightly higher after treatment with thyroxine plus triiodothyronine, but mean blood-pressure values and neurophysiologic findings were similar after the two treatments.

Scores pertaining to cognitive functioning and mood were within normal limits, except that patients were marginally less able to recall digit-symbol pairs correctly on the Digit Symbol Test after treatment with thyroxine alone (Table 3 ). Among the 17 comparisons, 6 pairs showed an advantage $(\mathrm{P}<0.05)$ for treatment with thyroxine plus triiodothyronine and none for treatment with thyroxine alone. 
Table 3. Psychometric Findings at the End of Each Treatment Period.*

TEST OR SCALE

Cognitive performance

Digit Symbol Test

Pairs recalled correctly

Time $(\mathrm{sec})$

Raw score

Digit Span Test

Backward recall of digits

Forward recall of digits

Visual Scanning Test

Time $(\mathrm{sec})$

Total correct

Errors

Mood scores

Beck Depression Inventory

Spielberger State-Trait Anxiety Inventory

Profile of Mood States

Global score

Fatigue-inertia

Depression-dejection

Anger-hostility

Confusion-bewilderment

Tension-anxiety

Vigor-activity

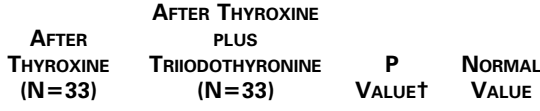

\section{$5.5 \pm 2.3$}

$58 \pm 15$

$48 \pm 12$

$6.3 \pm 2.1$

$56 \pm 16$

$\begin{array}{lll}57 \pm 12 & 0.76 & >43\end{array}$

0.04

$>6$

$\begin{array}{lll}6.0+1.3 & 0.05 & >5\end{array}$

$\begin{array}{llll}6.9 \pm 1.9 & 6.9 \pm 1.8 & 0.99 & >5\end{array}$

$\begin{array}{llll}75 \pm 23 & 71 \pm 25 & 0.15 & <120\end{array}$

$\begin{array}{llll}58 \pm 2 & 59 \pm 2 & 0.53 & >56\end{array}$

$\begin{array}{llll}1.7 \pm 1.8 & 1.5 \pm 2.1 & 0.58 & <3\end{array}$

$\begin{array}{llll}9.8 \pm 7.7 & 7.9 \pm 5.3 & 0.10 & <11\end{array}$

$\begin{array}{cccc}44 \pm 11 & 45 \pm 8 & 0.38 & <50\end{array}$

$33 \pm 28 \quad 24 \pm 24 \quad 0.01 \quad-$

$\begin{array}{llll}9.3 \pm 4.3 & 7.2 \pm 3.9 & 0.001<18\end{array}$

$\begin{array}{rrr}13.4 \pm 9.5 & 10.5 \pm 8.9 & 0.01\end{array}$

$\begin{array}{rrrr}9.1 \pm 7.3 & 7.3 \pm 5.2 & 0.04 & <17\end{array}$

$\begin{array}{llll}5.3 \pm 4.5 & 4.3 \pm 3.5 & 0.13 & <17\end{array}$

$\begin{array}{llll}8.5 \pm 5.3 & 7.7 \pm 5.4 & 0.23 & <21\end{array}$

$\begin{array}{rrrr}12.4 \pm 4.6 & 13.0 \pm 3.7 & 0.39 & >9\end{array}$

*Among the 17 tests, patients had better results after treatment with thyroxine plus triiodothyronine on $14 ; 6$ of these differences were significant $(\mathrm{P}<0.05)$. On two tests performance was better after thyroxine treatment; neither difference was significant. Forward recall of digits was essentially the same after both treatments. Plus-minus values are means $\pm S D$.

$\dagger \mathrm{P}$ values were calculated by paired $\mathrm{t}$-tests.

Performance after thyroxine-plus-triiodothyronine treatment was significantly better $(\mathrm{P}<0.05)$ on parts of two of the three tests of cognitive performance (Table 3). The higher scores for recall of pairs on the Digit Symbol Test indicated better incidental learning, and the higher scores for recalling digits in reverse order on the Digit Span Test indicated improved mental flexibility and attention.

The three self-rating mood scales pertained to depression, anxiety, or both. After thyroxine-plus-triiodothyronine treatment, the patients tended to be less depressed (shown by lower scores on the Beck Depression Inventory), and their global scores and scores on the three subscales (fatigue-inertia, depression-dejection, and anger-hostility) of the Profile of Mood States were significantly lower $(\mathrm{P}<0.05)$, indicating improvement, than scores after treatment with thyroxine alone (Table 3 ).

Eight visual-analogue scales pertained to mood and seven to physical symptoms (Table 4). Patients scored their mood as significantly better after thyroxine-plus-triiodothyronine treatment on seven of the eight mood scales $(\mathrm{P}<0.04)$ and scored their physical symptoms as significantly improved on three of seven scales $(\mathrm{P}<0.02)$. Patients reported only slight physical problems at both evaluations. Their mean visual-analogue scores were closer to "no symptoms" than to "severe symptoms" — that is, less than 50 , the middle of each test line.

When asked at the end of the study whether they preferred the first or second treatment, 20 patients preferred thyroxine plus triiodothyronine, $11 \mathrm{had}$ no preference, and 2 preferred thyroxine alone $(\mathrm{P}=$ $0.001)$. The order of treatment was unrelated to preference. The two patients who preferred thyroxine had noticed that they felt slightly "nervous" during combined treatment. The 20 patients who preferred thyroxine plus triiodothyronine had noticed that they were more energetic, had better concentration, and simply felt better. One woman became anxious during treatment with thyroxine plus triiodothyronine and was withdrawn from the study.

The order of treatment did not affect the results. To determine whether triiodothyronine was more beneficial in patients receiving either high ratios of triiodothyronine to thyroxine (i.e., those who received lower doses of thyroxine at base line) or low ratios, we compared the results from the 20 patients who were taking 100 to $150 \mu \mathrm{g}$ of thyroxine at base line with those from the 13 patients who were taking 200 to $300 \mu \mathrm{g}$. The results were similar in the two groups. There was also no difference between 
Table 4. Results on Visual-Analogue Scales at the End of Each Treatment Period.*

\begin{tabular}{|c|c|c|c|}
\hline SCALE & $\begin{array}{c}\text { AFTER } \\
\text { THYROXINE } \\
(\mathbf{N}=\mathbf{3 3})\end{array}$ & $\begin{array}{c}\text { AfTER THYROXINE } \\
\text { PLUS } \\
\text { TRIIODOTHYRONINE } \\
\text { (N=33) }\end{array}$ & $\begin{array}{c}\mathbf{P} \\
\text { VALUE } \dagger\end{array}$ \\
\hline \multicolumn{4}{|l|}{ Mood } \\
\hline Sad & $40 \pm 24$ & $26 \pm 19$ & $<0.001$ \\
\hline Confused & $34 \pm 24$ & $23 \pm 20$ & $<0.001$ \\
\hline Fearful & $30 \pm 29$ & $20 \pm 22$ & 0.001 \\
\hline Irritable & $39 \pm 28$ & $27 \pm 22$ & 0.002 \\
\hline Tense & $42 \pm 29$ & $28 \pm 23$ & 0.007 \\
\hline Angry & $32 \pm 28$ & $25 \pm 20$ & 0.02 \\
\hline Tired & $49 \pm 26$ & $39 \pm 28$ & 0.04 \\
\hline Agitated & $39 \pm 30$ & $34 \pm 26$ & 0.18 \\
\hline \multicolumn{4}{|l|}{ Physical symptoms } \\
\hline Feel cold & $37 \pm 27$ & $23 \pm 24$ & 0.004 \\
\hline Blurred vision & $30 \pm 29$ & $22 \pm 27$ & 0.01 \\
\hline Nauseated & $22 \pm 23$ & $13 \pm 17$ & 0.02 \\
\hline Sleepy & $39 \pm 29$ & $29 \pm 27$ & 0.09 \\
\hline Light-headed & $35 \pm 26$ & $31 \pm 28$ & 0.22 \\
\hline Drowsy & $36 \pm 27$ & $31 \pm 25$ & 0.29 \\
\hline Feel hot & $24 \pm 21$ & $25 \pm 27$ & 0.80 \\
\hline
\end{tabular}

* On every scale, a lower score represents a more favorable state. Scores of 0 or 100 are theoretically possible but are rarely encountered. Plus-minus values are means $\pm S D$.

$\dagger P$ values were calculated by paired $t$-tests.

the responses of the 4 patients with depression and those of the 29 patients without depression. Finally, the advantage of thyroxine plus triiodothyronine was not limited to only a few patients. Analysis of the psychological variables for which combined therapy was most beneficial (Tables 3 and 4) showed that most patients derived at least some benefit from the addition of triiodothyronine (data not shown).

\section{DISCUSSION}

Patients with hypothyroidism benefited when $12.5 \mu \mathrm{g}$ of triiodothyronine was substituted for 50 $\mu \mathrm{g}$ of thyroxine in their treatment regimens. They performed better on standard neuropsychological tasks, and their psychological state improved. The differences in most physiologic variables were slight, but in any case, these are insensitive indicators of thyroid hormone actions. Pulse rates and serum sex hormone-binding globulin concentrations were higher after treatment with thyroxine plus triiodothyronine, indicating a slightly greater effect on the heart and liver. ${ }^{7}$ Serum thyroxine concentrations were lower and triiodothyronine concentrations were higher after treatment with thyroxine plus triiodothyronine, but serum thyrotropin concentrations, a sensitive measure of thyroid hormone action, were similar after the two treatments. The apparent difference in physiologic responses could reflect differences in tissue uptake of the hormones, in the conversion of thyroxine to triiodothyronine, or in thyroid hormone receptors. ${ }^{15,16}$
The variables related to mental function for which the substitution of triiodothyronine resulted in benefit require fuller description. On tests of cognitive performance and self-rating scales for mood, patients scored in the normal range on 16 of 17 measures after both treatments (Table 3), but on 6 of the tests or scales they performed or felt significantly better after receiving thyroxine plus triiodothyronine. These results were reinforced by results on the visual-analogue scales. No test result was better after treatment with thyroxine alone. It seems clear that treatment with thyroxine plus triiodothyronine improved the quality of life for most patients. We think that five weeks was probably long enough for the maximal effect of the treatments to be detected, but we cannot be sure.

Despite these results, it is clear that the substitution of triiodothyronine for a portion of regular thyroxine therapy is not sufficient treatment for depression, because the 4 depressed patients benefited from triiodothyronine substitution no more than the other 29 patients. Nevertheless, in depressed patients who have normal thyroid hormone concentrations, the addition of triiodothyronine to standard antidepressant-drug treatment can be beneficial. ${ }^{17}$

This study extends two others in which different regimens of thyroxine and triiodothyronine were compared. In one study, in which the doses were much higher than those used in this study, the patients preferred thyroxine alone, because it was somewhat less toxic. ${ }^{18}$ In the other, an open trial involving nine depressed patients who were receiving thyroxinereplacement therapy but were responding poorly to an antidepressant drug, the addition of triiodothyronine ( 15 to $50 \mu \mathrm{g}$ daily) to thyroxine (rather than the substitution of triiodothyronine) resulted in a marked decrease in depression in seven patients. ${ }^{19}$

There are at least two ways in which the use of thyroxine alone for replacement therapy might deprive the brain of triiodothyronine. First, delivery of triiodothyronine through the circulation, the source of about 20 percent of the triiodothyronine in the rat brain, ${ }^{20}$ is deficient to the extent that thyroid glandular secretion is deficient unless compensated for by production in peripheral tissues. Second, circulating thyroxine, and presumably thyroxine in the brain, will be increased, and in the brain thyroxine down-regulates its own conversion to triiodothyronine. ${ }^{21}$ However, the two hormones are differently bound to plasma proteins and may be differently delivered to the brain. ${ }^{22}$

The daily production of triiodothyronine by the human thyroid gland is about $6 \mu \mathrm{g}^{23}$; the rate of absorption of ingested triiodothyronine is almost 100 percent. ${ }^{24}$ Thus, the dose of triiodothyronine given in the present study somewhat exceeded the normal glandular production. The ideal replacement regimen when thyroid-gland function is absent or nearly 
absent might consist of $10 \mu \mathrm{g}$ of triiodothyronine daily in sustained-release form (because the hormone is rapidly absorbed and metabolized), along with enough thyroxine to ensure euthyroidism.

We conclude that in patients with hypothyroidism, partial substitution of triiodothyronine for thyroxine may have more salutary effects on the brain and perhaps other tissues than those of an equivalent amount of thyroxine, as determined by their effects on thyrotropin secretion. This finding suggests that thyroidal secretion of triiodothyronine is physiologically important.

We are indebted to Susan Silva, Ph.D., for her advice regarding the choice of psychometric tests and statistical methods, to Mr. Robert Ekstrom for statistical assistance, and to Berlin-Chemie (Berlin, Germany) for the supplies of thyroxine and triiodothyronine.

\section{REFERENCES}

1. Leonard JL, Koehrle J. Intracellular pathways of iodothyronine metabolism. In: Braverman LE, Utiger RD, eds. Werner and Ingbar's the thyroid: a fundamental and clinical text. 7th ed. Philadelphia: Lippincott-Raven, 1996:125-61.

2. Visser TJ, Leonard JL, Kaplan MM, Larsen PR. Kinetic evidence suggesting two mechanisms for iodothyronine $5^{\prime}$-deiodination in rat cerebral cortex. Proc Natl Acad Sci U S A 1982;79:5080-4.

3. Taylor S, Kapur M, Adie R. Combined thyroxine and triiodothyronine for thyroid replacement therapy. BMJ 1970;2:270-1.

4. Hamilton M. A rating scale for depression. J Neurol Neurosurg Psychiatry 1960;23:56-62.

5. Diagnostic and statistical manual of mental disorders, 3rd ed. rev.: DSM-III-R. Washington, D.C.: American Psychiatric Association, 1987. 6. Spitzer RL, Williams JBW, Gibbon M, First MB. User's guide for the structured clinical interview for DSM-III-R. Washington, D.C.: American Psychiatric Press, 1990.

7. Sarne DH, Refetoff S, Rosenfield RL, Farriaux JP. Sex hormone-binding globulin in the diagnosis of peripheral tissue resistance to thyroid hormone: the value of changes after short term triiodothyronine administration. J Clin Endocrinol Metab 1988;66:740-6.
8. Dyck PJ, Zimmerman IR, O'Brien PC et al. Introduction to automated systems to evaluate touch-pressure vibration, and thermal cutaneous sensation in man. Ann Neurol 1978;4:502-10.

9. Kimura J. Electrodiagnosis in diseases of nerve and muscle: principles and practice. 2nd ed. Philadelphia: F.A. Davis, 1989.

10. Wechsler D. WAIS-R manual: Wechsler adult intelligence scale. Rev. New York: Harcourt Brace Jovanovich, 1981.

11. Weintraub S, Mesulam M-M. Mental state assessment of young and elderly adults in behavioral neurology. In: Mesulam M-M, ed. Principles of behavioral neurology. Vol. 26 of Contemporary neurology series. Philadelphia: F.A. Davis, 1985:71-123.

12. Beck AT, Ward CH, Mendelson M, Mock J, Erbaugh J. An inventory for measuring depression. Arch Gen Psychiatry 1961;4:561-71.

13. Spielberger CD, Gorsuch RL, Lushene R, Vagg PR, Jacobs GA. Manual for the state-trait anxiety inventory (form Y). Palo Alto, Calif.: Consulting Psychologists Press, 1983.

14. McNair DM, Lorr M, Droppleman LF. Profile of mood states revised. San Diego, Calif.: Educational and Institutional Testing Service, 1992

15. Hodin RA, Lazar MA, Chin WW. Differential and tissue-specific regulation of the multiple rat c-erbA messenger RNA species by thyroid hormone. J Clin Invest 1990;85:101-5.

16. Lazar MA. Thyroid hormone receptors: multiple forms, multiple possibilities. Endocr Rev 1993;14:184-93.

17. Esposito S, Prange AJ Jr, Golden RN. The thyroid axis and mood disorders: overview and future prospects. Psychopharmacol Bull 1997;33: 205-17.

18. Smith RN, Taylor SA, Massey JC. Controlled clinical trial of combined triiodothyronine and thyroxine in the treatment of hypothyroidism. BMJ 1970;4:145-8.

19. Cooke RG, Joffe RT, Levitt $A J$. $T_{3}$ augmentation of antidepressant treatment in $\mathrm{T}_{4}$-replaced thyroid patients. J Clin Psychiatry 1992;53:16-8. 20. Silva JE, Matthews PS. Production rates and turnover of triiodothyronine in rat-developing cerebral cortex and cerebellum: responses to hypothyroidism. J Clin Invest 1984;74:1035-49.

21. Silva JE, Leonard JL. Regulation of rat cerebrocortical and adenohypophyseal type II 5 -deiodinase by thyroxine, triiodothyronine, and reverse triiodothyronine. Endocrinology 1985;116:1627-35.

22. Terasaki T, Pardridge WM. Differential binding of thyroxine and triiodothyronine to acidic isoforms of thyroid hormone binding globulin in human serum. Biochemistry 1988;27:3624-8.

23. Pilo A, Iervasi G, Vitek F, Ferdeghini M, Cazzuola F, Bianchi R. Thyroidal and peripheral production of $3,5,3^{\prime}$-triiodothyronine in humans by multicompartmental analysis. Am J Physiol 1990;258:E715-E726.

24. Brent GA, Larsen PR. Treatment of hypothyroidism. In: Braverman LE, Utiger RD, eds. Werner and Ingbar's the thyroid: a fundamental and clinical text. 7th ed. Philadelphia: Lippincott-Raven, 1996:883-7. 